\title{
Profile of oncological diseases in dogs and clinical effectiveness of autovaccine therapy of papillomatosis
}

\author{
[Perfil de doenças oncológicas em caninos e eficácia clínica da terapia com \\ autovacina em papilomatose]
}

\section{N.A. Kudacheva}

Samara State Agricultural Academy - Kinel, Russian Federation

\begin{abstract}
Papillomatosis is one of the few diseases in which autovaccine therapy is recommended, especially in the case of mass manifestation in animals. It is noted that papillomas are diagnosed in $15.7 \%$ of cases in histological diagnosis of oncological diseases. Therefore, this work studied the profile of oncological diseases in dogs and the clinical effectiveness of autovaccine therapy of papillomatosis. The article gives a morphological description of papillomas used as a biomaterial, and also describes the technological methods of manufacturing an autovaccine used to treat animals against papillomatosis. A therapeutic scheme for administering the vaccine was proposed and tested, and the results of the clinical trial are presented, as well as a reflection on some moments of the mechanism of vaccine therapy for papillomatosis.
\end{abstract}

Keywords: papilloma, autovaccine, immunotherapy, koylocytosis, papillomatosis

\section{RESUMO}

A papilomatose é uma das poucas doenças onde se recomenda a terapia com autovacina, principalmente no caso de manifestação em massa em animais. Nota-se que papilomas são diagnosticados em 15,7\% dos casos em diagnóstico histológico de doenças oncológicas. Portanto, este trabalho estudou o perfil das doenças oncológicas em cães e a eficácia clínica da terapia com autovacina em papilomatose. O presente artigo fornece descrição morfológica dos papilomas utilizados como biomaterial, além da descrição dos métodos tecnológicos de fabricação de uma autovacina usada para tratar animais contra a papilomatose. Um esquema terapêutico para a administração da vacina foi proposto e testado, e os resultados do ensaio clínico são apresentados, e é feita uma reflexão sobre alguns momentos do mecanismo da terapia de vacina para papilomatose.

Palavras-chave: papiloma, autovacina, imunoterapia, klococitose, papilomatose

\section{INTRODUCTION}

Nowadays autovaccination is one of the types of specific immunotherapy, including in diseases of viral etiology, in particular in papillomatosis of animals. The simplest way of making vaccines is to use inactivated tumor cells obtained from the same sick animal for which the vaccine (autologous cells) is prepared. The advantage of autovaccine in this case is that their composition is represented by the whole spectrum of antigens against which an immune response is intended, including individual and stadiospecific antigens that distinguish the development of tumor growth (Potebnya et al., 2002).
Animal papillomatosis is currently one of the most promising diseases in the study of mechanisms of vaccine therapy, not only in veterinary medicine, but also in medicine, and in most cases it is connected with the therapeutic direction in oncology (Kanashkova et al., 2009). The effectiveness of vaccines used can be enhanced by increasing immunogenicity, which is achieved in various ways, including the simultaneous administration of nonspecific immunotherapeutic drugs, both independently and as part of biologics (Terekhov, 1983). The introduction of vaccines in viral infections with a therapeutic purpose in veterinary medicine has 
limited use, which is primarily due to the development of viremia, on the background of which postvaccinal complications occur, in the form of post-vaccination infections.

The effectiveness of using such vaccines does not always cause clinical recovery and, according to the literature, attention should be paid to the inactivation of the pathogen, in order to exclude the possibility of generalization of the infectious process when it is introduced (Veremey and Komarovsky, 2006; Campo et al., 1993; Sigueira and Marins, 2011).

\section{MATERIALS AND METHODS}

The research was carried out on the basis of veterinary clinics in the city of Samara. The research sample included sick dogs, whose owners sought the assistance of a veterinarian between 2013 and 2017. Previously, an epizootic and clinical examination was carried out, followed by a histological diagnosis that allowed the final diagnosis of papillomatosis on the basis of specific signs of koylocytic atypia of epithelial cells (Kudacheva, 2014).

11 dogs were included in the study program, regardless of the localization of neoplasms, but all animals presented a cutaneous form of the disease, without mucosal lesions. In clinical trials, after the diagnosis of papillomatosis, a subcutaneous method of administering biologics made directly from single remote neoplasms was used. The criterion for surgical removal and subsequent use as a biomaterial was the following morphological characteristics of papillomas: the largest size in comparison with others; the surface of the papilloma with signs of hyperkeratosis; has the highest density when performing palpation.

The vaccine was manufactured by the original method, with the addition of non-pathogenic bacteria from the genus Bacillus. After the tumor cell mass was obtained, the resulting tissue suspension was diluted with physiological solution to a certain volume, poured into vials, sealed and autoclaved under the appropriate regimen. The scheme of vaccine therapy included 3 administrations of the biopreparation with an interval of 4 days, the dose was calculated on the basis of the live weight of the animal $-0.5 \mathrm{ml}$ per $1 \mathrm{~kg}$ of the animal.

\section{RESULTS AND DISCUSSION}

When studying the profile of oncological diseases in dogs, one should note the prevalence of mesenchymal tumors, which constitute $36.7 \%$ of the total number of confirmed histological oncological diseases. Tumors of epithelial origin as a whole make up $23.7 \%$, and in prevalence they occupy the second place among all diagnosed groups of neoplasms. In this case, papillomatosis, related to epithelial tumors without specific localization, in the profile studied was $15.5 \%$. The results obtained for the spread of dog cancers, taking into account their morphological classification, are shown in Table 1.

Papillomatosis in dogs can only be controlled if pet owners contact veterinary clinics. But usually this does not happen for various reasons. As a rule, animal owners in this case use the tactics of "waiting" and spontaneous cure of animals from papillomatosis, without using any therapeutic means, which further increases the incidence and manifestation of infection in the form of a characteristic clinical picture, with multiple lesions.

Mass manifestation of papillomatosis is associated with many factors, including immunodeficiency states, both primary and secondary nature (Veremey and Komarovsky, 2006; Campo et al., 1993). The identification of dogs with a clinical picture of papillomatosis by year (from 2013 to 2017) is shown in Figure 1.

Clinical and histological diagnostics were the basis for identifying papillomas and setting the final diagnosis for papillomatosis, other methods in our case are practically impossible, including those aimed at isolating the virus or its genome in the material under investigation. Clinically, the consistency of the lesions is fairly dense and their structure is represented by a well expressed stroma consisting of loose or dense fibrous connective tissue, which is confirmed by histological studies (Figure 2).

Parenchyma in structure corresponds to the layered structure of the skin, but with pronounced hyperplasia of the basal and spine-like layers. The spine-like layer is unevenly thickened, eosinophilic, with the presence of signs of koilocytosis (Caparica et al., 2018). Koilocytosis is predominantly noted in the upper part of the 
epidermis, which forms the papilloma parenchyma. Koilocytes are located in the form of focal congestions or diffusely, the shape is rounded, have a slight polymorphism. Polymorphism is determined by the location of cells relative to the surface of the papilloma shear, with the location in the lower sections of the spine-like layer, the koilocytes have a regular roundness, rarely a slight flattening, with the nucleus somewhat displaced from the center of the cell to its peripheral part. The cytoplasm is enlightened, but it is evenly colored. Closer to the horny layer of the epidermis, the koilocytes increase in size, the cells acquire a more flattened or ovoid form, the nucleus is displaced to the cytoplasmic membrane and is in a state of pycnosis. The surface of the epithelium in the state of hyperkeratosis, consisting of keratinized cells.

Table 1. Dog cancers in accordance with the morphological classification of tumors

\begin{tabular}{|c|c|c|}
\hline № п/ா & $\begin{array}{l}\text { Group of neoplasms } \\
\text { and type of tumor }\end{array}$ & $\begin{array}{c}\% \text { of the total number } \\
\text { of dogs studied }\end{array}$ \\
\hline 1 & Epithelial tumors without specific localization (organ- nonspecific): & \\
\hline & & 23.7 \\
\hline 1.1 & papilloma & 15.7 \\
\hline 1.2 & squamous cell skin cancer & 5.3 \\
\hline 1.3 & basal cell & 2.7 \\
\hline 2 & $\begin{array}{l}\text { Tumors of exo- and endocrine glands, as well as of epithelial } \\
\text { integument (organ-specific): }\end{array}$ & 18.3 \\
\hline 2.1 & seminoma & 3.4 \\
\hline 2.2 & mammary cancer & 15.1 \\
\hline 3 & Mesenchymal tumors: & 36.7 \\
\hline 3.1 & lipoma & 10.3 \\
\hline 3.2 & fibroma & 11.1 \\
\hline 3.3 & fibrolipoma & 5.1 \\
\hline 3.4 & rhabdomyoma & 4.1 \\
\hline 3.5 & chondrosarcoma & 2.0 \\
\hline 3.6 & myosarcoma & 1.8 \\
\hline 3.7 & liposarcoma & 2.3 \\
\hline 4 & Tumors of melanin-forming tissue: & 15.2 \\
\hline 4.1 & nevus & 1.2 \\
\hline 4.2 & melanoma & 14.0 \\
\hline 5 & Tumors of the blood system & 5.9 \\
\hline 5.1 & myeloid leukemia & 1.9 \\
\hline 5.2 & lymphosarcoma & 4.0 \\
\hline 6 & Teratoms & 0.2 \\
\hline
\end{tabular}

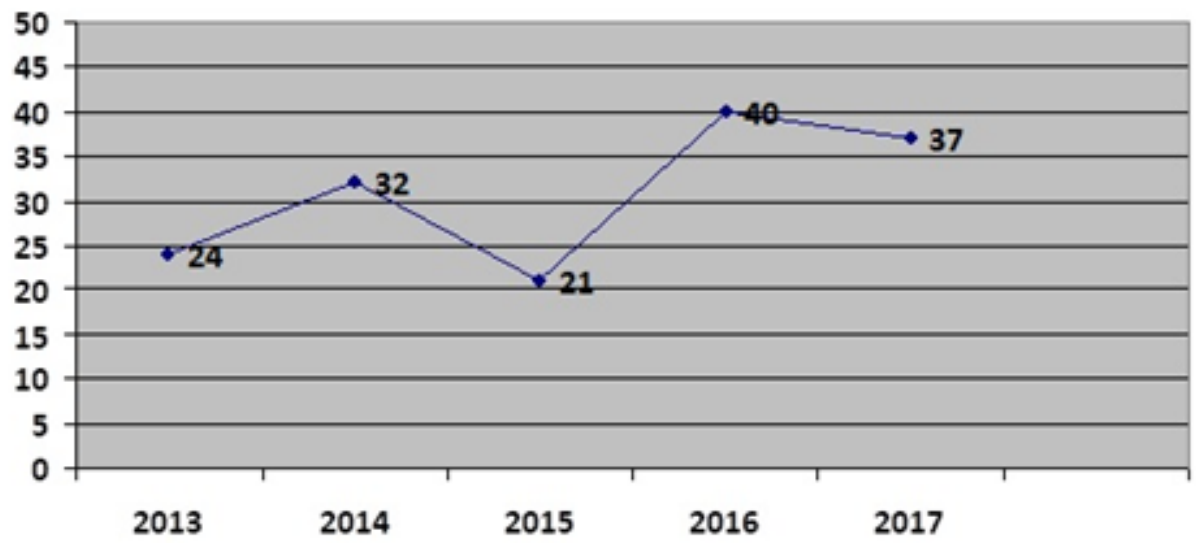

Figure 1. Number of identified clinical cases papillomatosis of dogs from 2013 to 2017. 


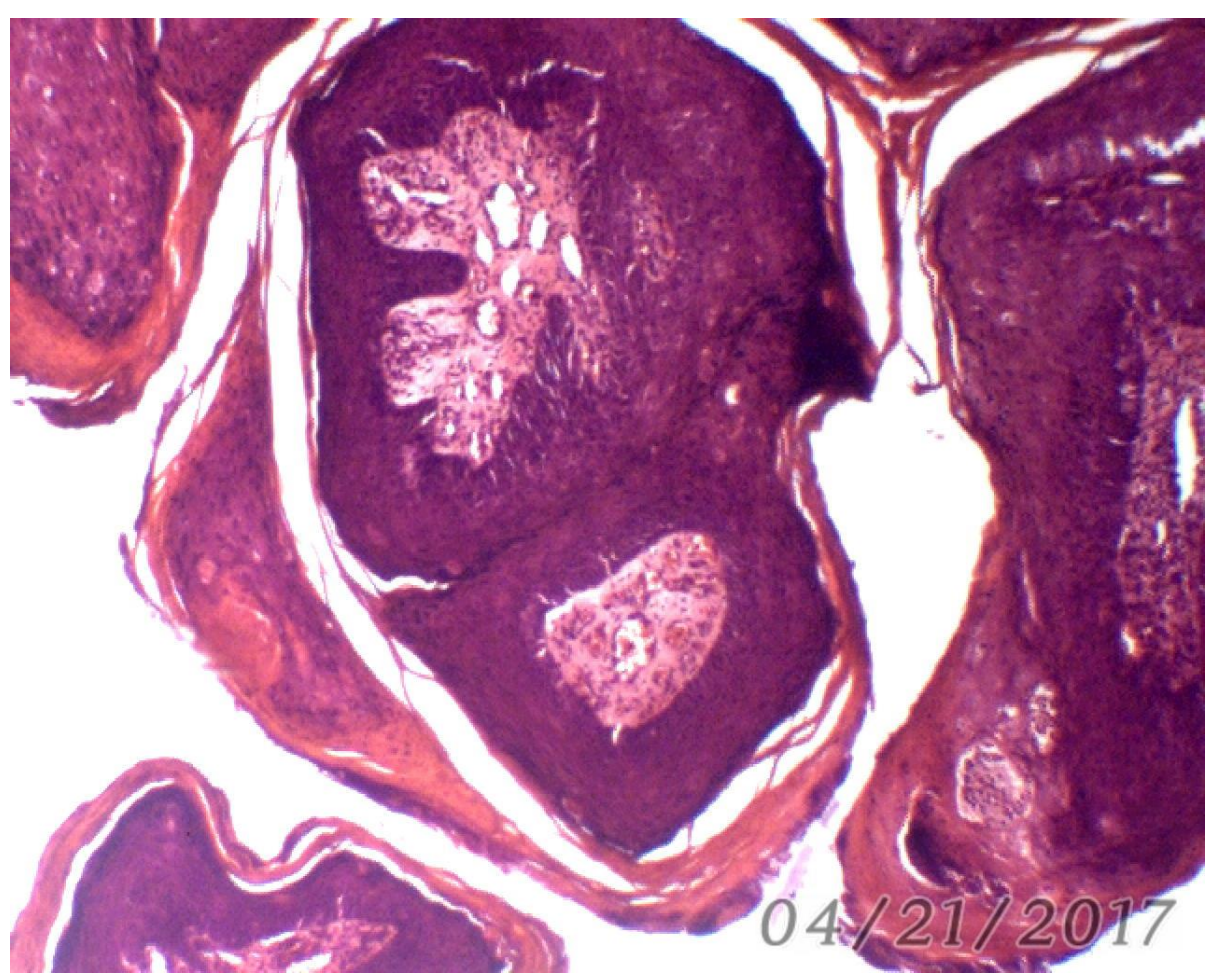

Figure 2. Histological structure of papillomas. Coloration of hematoxylin eosin.

It is quite reasonable in our case to use complex therapy with the use of specific etiotropic (antiviral) and local remedies. This does not reduce the effectiveness of the vaccine, but does not allow us to track its therapeutic effect, so we limited ourselves to its use. As the practical experience shows, the absence of specific biological drugs, including papillomatosis, promotes the preservation of the pathogen in latent infected animals, with the subsequent development of all new clinical cases or epizootics of papillomatosis.

Taking into account the peculiarities of the pathogenesis of papillomatosis and its belonging to a group of oncological diseases of benign nature, it is necessary to use an adjuvant that enhances the immune response. It is very difficult in the process of manufacturing the vaccine to obtain the necessary amount of biomass, which allows to produce enough doses for use. Therefore, it is necessary to strengthen the immunotherapeutic effect by using nonspecific immunostimulant components.
As a result of studying the properties of various microorganisms for effective autovaccine therapy, a microorganism from the genus Bacillus possessing antitumor properties (Zatula, 1985) is recommended as an adjuvant, which was also used in our case. As the vaccine was administered, the animal under study did not show a marked temperature response, as well as changes in the place of administration of the vaccine.

The clinical effect of autovaccine therapy was observed after the second administration of the biopreparation. It consisted in a decrease in the size of the papillomas, the process most noticeable from the side of papillomas with signs of hyperkeratosis. With skin lesions, the papillomas regressed by decreasing neoplasms in diameter, the diameter of the base remaining the same, and the height above the surface of the skin becoming much smaller. When palpation also marked the smoothing of the papillary structure of the surface, its darkening and drying. The effectiveness of vaccine therapy in the animals is shown in Table 2. 
Table 2. Clinical efficacy of vaccine therapy in the animals studied

\begin{tabular}{cccc}
\hline Number of animals & $\begin{array}{c}\text { Complete regression, } \\
\text { number of }(\%)\end{array}$ & $\begin{array}{c}\text { Partial regression, } \\
\text { number of }(\%)\end{array}$ & $\begin{array}{c}\text { Dissemination of } \\
\text { oncoprocess number of } \\
(\%)\end{array}$ \\
\hline 11 & $\begin{array}{c}\text { On the 20th day of therapy } \\
2(18.18)\end{array}$ & $1(9.09)$ \\
11 & $\begin{array}{c}\text { On the 30th day of therapy } \\
0(0)\end{array}$ & $0(0)$ \\
\hline
\end{tabular}

\section{CONCLUSION}

The mechanisms of vaccine therapy are quite complex and are not described in practice in veterinary medicine, especially with infectious oncological diseases. It should be noted that benign neoplasms, localized in our case on the skin (dermal disseminated papillomatosis), are characteristic of papillomatosis. The independent structure of the blood supply and innervation allows the papillomas to pass through all the stages of growth and development, with the loss in the future of the basic function of the skin. Theoretically, the presence of its own blood supply in turn provokes a direct effect of antibodies on the virus, which is in the structural elements of papillomas. The absence of a virus in the blood (viremia) does not reduce the activity of specific antibodies acting selectively. Such studies do not allow us to go into more detail on the specific and nonspecific mechanisms of the vaccine used, and further research is required, but the clinical trials that have been carried out still allow us to confirm the sufficiently high clinical efficacy of the manufactured biopreparation. Clinical efficacy on the 30th day of the studies was $100 \%$. In one dog, against the background of vaccine therapy on the 20th day, new papillomas with high growth rates appeared, but later quickly regressed (by the 30th day of observation). Probably, this could be due to technological errors in the manufacture of a biopreparation for a given $\mathrm{dog}$, as a result of which the inactivation of the biomaterial was insufficient. Proceeding from the foregoing, our vaccine, containing as an adjuvant a microorganism from the genus Bacillus, possessing nonspecific immunostimulating action, showed a positive therapeutic effect.

\section{REFERENCES}

CAMPO, M.S.; JARRETT, W.F.H.; GRINDLAY, G.J. et al. Prophylactic and therapeutic vaccination against a mucosal papillomavirus. J. Gen. Virol., v.74, p.945953,1993

CAPARICA, R.; MACENA, J.C.; CAMARGO, L.E.A. Albumin nanoparticles: An interesting alternative for the controlled release of drugs. Period. Quim., v.15, p.705-715, 2018.

KANASHKOVA, T.A.; SHABAN, ZH.G.; CHERNOSHA, D.A. Specific immunoprophylaxis and immunotherapy of infectious diseases. Minsk: BGMU, 2009. 84p.

KUDACHEVA, N.A. Koilocytic atypia of the epithelium as a cytomorphological criterion for diagnosis of papillomatosis. Actual problems of the development of veterinary science. In: INTERNATIONAL CONFERENCE DEDICATED TO THE 85TH ANNIVERSARY OF THE SAMARA VETERINARY STATION OF THE RUSSIAN ACADEMY OF AGRICULTURAL SCIENCES. STATE SCIENTIFIC ESTABLISHMENT OF SAMARA AGRICULTURAL RESEARCH INSTITUTE OF THE RUSSIAN ACADEMY OF AGRICULTURAL SCIENCES, 2014, Samara. Proceedings... Samara: [s.n.], 2014. p.193-196.

POTEBNYA, G.P.; LISOVENKO, G.S.; YALKUT, S.I. Antineoplastic autovaccines: prospects of use. Doctor, v.2, p.32-35, 2002.

SIGUEIRA, D.R.; MARINS Q.S. Inactivated autogenous vaccine associated with hemotherapy and application of Thuya occidentalis in the homeopathic treatment of canine oral papillomatosis - a case report. Afr. J. Pharm. Pharmacol. Res., v.1, p.7-11, 2011.

TEREKHOV, P.F. Veterinary clinical oncology. Moscow: Kolos, 1983. 208p.

VEREMEY, E.I.; KOMAROVSKY, V.A. Recommendations for the integrated treatment of cattle in papillomatosis. Vitebsk: VGAVM, 2006. 14p.

ZATULA, D.G. Microorganisms, cancer and antitumor immunity. Kyiv: Naukova Dumka, 1985. 213p. 